\title{
Fra forsamlingshuset over idrætshallen til multiaktivitetshuset
}

Af Sine Agergaard

I denne artikel beskrives tre bygninger som billeder på udviklingen af den folkelige gymnastik- og idrætshistorie gennem det sidste århundrede. Det er Hover Forsamlingshus (som blev bygget i 1891 og afløst af et nyere byggeri i 1927), Højmarkhallen (indviet i 1966) og DGI-huset i Århus (indviet i 2003). Her fokuseres altså på ganske få eksempler på gymnastik- og idrætsrum i Vest- og Østjylland, mens de generelle træk i udviklingen af idrættens rum i Danmark er beskrevet mere udførligt andetsteds. ${ }^{1}$ Ikke desto mindre giver et kulturhistorisk perspektiv på de tre udvalgte idrætsrum et kondenseret indblik i en mikrohistorie, der belyser den makrohistoriske fortælling om den folkelige idræt. Beskrivelserne vil uddybe, hvordan idrætsbygningerne på én gang viser en historisk kontinuitet med det mønster af folkelige aktiviteter, der udviklede sig sidst i 1800tallet, og samtidig afspejler, hvordan folkelighedsbegrebet har ændret sig. ${ }^{2}$

Empirinære studier af rum kan således fortælle om den idrætshistoriske udvikling, hvor de idealer og praksisformer, der går forud for vores tid, sætter sig spor i de idrætsfaciliteter, som vi nu færdes i. De tre udvalgte rum er illustrative for tre centrale faser i byggeriet af idrætsfaciliteter i Danmark, nemlig oprettelsen af et stort antal forsamlingshuse i landsbysogne o. år 1900, det såkaldte halboom i 1960'erne og det eksperimenterende idrætsbyggeri fra midten af 1990'erne og frem til i dag. De tre bygninger kan også betragtes som billeder på fremgangen for henholdsvis det agrare, det industrielle og det postindustrielle samfund. ${ }^{3}$ Det er dog ikke samfundsudviklingen, der vil være i fokus her, men derimod den idrætshistorie, som bliver levet i de konkrete bygninger.

\section{Materiale og metodisk tilgang}

Analysen af forsamlingshuset, idrætshallen og multiaktivitetshuset er baseret på lokalhistorisk materiale og på etnografiske deltagerobservationer i rummene. Der er det særlige ved de foretagne deltagerobservationer, at de i høj grad kan karakteriseres som retrospektive deltagerobservationer. Uddannelsen i etnografi med metodeøvelser og kulturteorier har nemlig påvirket min forståelse af de idrætsfaciliteter, som jeg allerede forud for etnografistudiet kendte som deltager. Desuden er mine erindringer blevet korrigeret gennem opfølgende observationer og interviews med nogle af de lokale, som stadig er bosat ved og fungerer som enten brugere eller ledere af idrætsfaciliteterne.

Til forskel fra etnografer, der drager på feltarbejde til fjerne samfund, har min fordel været, at jeg allerede taler sproget (den vestjyske og efterhånden også den århusianske dialekt) og kender til de kulturelle værdier, der kommer til udtryk i informanternes ydmyge og begejstrede fortællinger. 
Ulempen kan imidlertid være, at de udvalgte idrætsfaciliteter bliver betragtet med kulturspecifikke briller, nemlig med et perspektiv, der er formet af min baggrund i den såkaldt folkelige idræt, som ikke desto mindre vil blive gjort til genstand for analyse her. De gennemgående spørgsmål i artiklen vil være: 1 . Hvordan kommer det folkelige idrætsbegreb til udtryk i de udvalgte idrætsfaciliteter? og 2. Hvordan overleveres (og forandres) idealet om at forene det åndelige og det legemlige i de specifikke rum?

Fortællingen om de tre idrætsfaciliteter er samtidig fortællingen om min personlige idrætshistorie, der startede med gymnastik i det lokale forsamlingshus og fortsatte med gymnastik, idræt og ikke mindst fester i idrætshallen sammen med andre unge fra oplandet. En idrætshistorie, der p.t. er på nedtrapning i multiaktivitetshuset, hvor man kan deltage på gymnastik- og idrætshold under samme tag som individuel motionsudøvelse og offentlige sundhedsprojekter.

Det er således ikke uden forbehold, at jeg i det følgende vil analysere en række rum, som allerede er velkendte for mig. Som Verner Møller har påpeget, er det umanerligt svært at objektivere steder, som har evnen til at vække og binde følelser. ${ }^{4}$ Andetsteds har jeg beskrevet, hvorledes historiske repræsentationer af folkelige idræts- og dannelsesrum er kendetegnet ved det, som den kinesisk-amerikanske geograf $\mathrm{Yi}-\mathrm{Fu}$ Tuan kalder topifili. ${ }^{5}$ Tuan definerer topofili som de affektive bånd, der knytter folk til et sted. ${ }^{6}$ Topofilibegrebet kan her betegne den følelsesmæssige tilknytning til en specifik idrætsbygning, som jeg har fundet er gennemgående i skriftligt materiale om bygningerne (bl.a. jubilæumsskrifter), men også ved samtaler med dem, der i dag opholder sig i forsamlingshuset og idrætshallen i det vestjyske, såvel som i multiaktivitetshuset $\mathrm{i}$ byen.
Niels Kayser Nielsen oversætter topofilibegrebet med stedsans og forbinder det til følelser af lokalpatriotisme og stedsstolthed. ${ }^{7}$ Disse dimensioner er for mig at se især gældende ved forsamlingshuset og idrætshallen, hvor man mere eller mindre eksplicit giver udtryk for stolthed over sit sted. Lokalbefolkningens og de ansvarliges engagement $i$ forhold til deres idrætsfaciliteter har betydning for måden, hvorpå den folkelige idrætsideologi er indbygget $i$ rummene, og for hvordan faciliteterne vedligeholdes og anvendes i dag. Det kan være svært og måske endda uinteressant at skelne mellem ideen bag opbygningen af et rum og de aktiviteter, der foregår på stedet. Opgaven er derimod at afsøge, hvordan den folkelige idrætsideologi har udviklet sig i tæt sammenhæng med praksis i de specifikke rum.

Udviklingen vil blive belyst ved hjælp af en komparation mellem forsamlingshusets, idrætshallens og multiaktivitetshusets lokalhistorie på den ene side og beskrivelser af aktuelle begivenheder i bygningerne på den anden side. Dette dobbelte perspektiv anlægges med henblik på at analysere, hvorledes historien er tilstedeværende i vore aktuelle omgivelser. En analytisk tilgang, som er inspireret af den britiske antropolog Tim Ingold.

\section{Idratsfaciliteter som kultur- historiske praksislandskaber}

Ingolds udgangspunkt er en kritik af både naturalistiske beskrivelser af rum som en neutral baggrund og kulturalistiske analyser af specifikke steders symbolske betydning. ${ }^{8}$ Analyser af et landskab adskiller sig dels fra kartografiske analyser, hvor målet er at repræsentere et objektivt billede af rum som »space «, og dels fra symbolske 
analyser af steder som "places «, der bliver afskåret fra landskabet som sådant. Ud fra et fænomenologisk perspektiv søger Ingold at sammentænke det ydre og indre, det objektive og subjektive samt det materielle og idemæssige. Det er ligeledes med en interesse for sammenhængen mellem ydre træk ved rummet og folkets indre mentalitetshistorie, mellem rummets objektive funktion og de subjektive oplevelser deri samt mellem den materielle udformning og specifikke idealer for byggeriet, at de udvalgte idrætsfaciliteter her analyseres som kulturhistoriske landskaber.

Ingold definerer landskabet som den verden, man lærer at kende ved at opholde og bevæge sig deri. Desuden opfordrer Ingold til at »dvæle « ved de historier, der konstituerer et landskab. Metodisk set gælder det altså om at unders $ø$ ge landskabet på en måde, så historien bliver sammenholdt med de aktiviteter, der udspiller sig i de konkrete idrætsfaciliteter. I analysen af, hvorledes landskabet afspejler det arbejde og liv, som tidligere generationer har lagt $\mathrm{i}$ det, viser landskabets tidslige karakter sig. Ifølge Ingold udfoldes tidsligheden ikke i en beskrivelse af historiske begivenheder i kronologiske intervaller, men derimod i en analyse af, hvordan historiciteten smelter sammen med aktiviteter for de personer, der lever de historiske processer.

For at understrege, hvordan historien bliver videreført gennem praksis i et landskab, anvender Ingold begrebet »taskscape«, som her oversættes til begrebet praksislandskab. Det er et mønster af aktiviteter, der bliver udført af aktører således, at de i deres praksis har inkorporeret landskabet som helhed. Praksislandskabet er altså, når mennesker udfører aktiviteter, der har indlejret en specifik kulturhistorie i sig. Et eksempel på det kan være det mønster af folkelige aktiviteter, der videre- føres og forandres af dem, som bevæger sig i et forsamlingshus, en idrætshal eller et multiaktivitetshus.

Ingolds tilgang opfordrer således til at analysere idrætsbygninger som kulturhistoriske landskaber, hvor den historiske kontinuitet og forandring sammenholdes, og dikotomien fors øges nedbrudt mellem det objektive rum og det subjektive sted, der ofte er blevet anvendt ved studier af idrætsfaciliteter. ${ }^{9}$ Med begrebet $»$ praksislandskab « er det analytiske fokus ikke dybdegående på historien i sig selv, men derimod er der mulighed for at udvikle et nyt perspektiv på idrætshistorien, der sammenholder historien med praksisformer i et givet landskab.

\section{Forsamlingshuset $i$ det vestjyske landsbysogn}

Fra starten af 1870'erne til 1905 blev der bygget ca. 1000 forsamlingshuse i landsbyer i Danmark, og ved århundredskiftet havde næsten hver eneste landsby fået sit eget forsamlingshus. ${ }^{10}$ I Hover blev det første forsamlingshus bygget i 1891, hvilket i sig selv ikke er enestående, men snarere typisk for de små landsbysogne i egnen omkring Ringkøbing. ${ }^{11}$

Forsamlingshusene blev oprettet som led i et politisk, kulturelt og $\varnothing$ konomisk nybrud for landbefolkningen. Tidligere havde man holdt møder i sognets skolestuer, men med regulativer indført med den tiltagende politiske spænding i 1880'erne og ikke mindst med bøndernes voksende $\varnothing$ konomiske velstand blev det nødvendigt og muligt at oprette selvstændige forsamlingshuse. Forsamlingshuset i Hover, som kostede 1200 kr., blev finansieret via lån i Hover Sparekasse (oprettet i 1869) og frivillige bidrag. På listen over bidragyderne finder 
man 36 navne, heriblandt fire gårdmænd, som er registreret for det største beløb, nemlig 10,60 kr. om året i 5 år. ${ }^{12}$

Historien om forsamlingshuset i Hover er en kollektiv historie om den generation, som lagde et stort stykke arbejde i at introducere et mønster af folkelige aktiviteter (med møder, foredrag og fysiske aktiviteter) i landsbysognet. Relateret hertil er en række personhistorier. Eksempelvis fortæller historien om Kristen Kristensen om et pionerarbejde med at organisere skytte- og gymnastikaktiviteter i Hover. Efter et ophold på Ryslinge højskole i 1888-1889 kom Kristensen tilbage til Hover, hvor han den efterfølgende vinter bogstaveligt talt gik til gymnastik ved at tilbagelægge de 5$10 \mathrm{~km}$ til fods til nabosognene Ølstrup og No. Senere tog han sammen med andre unge i Hover initiativ til oprettelsen af Hover Skytteforening i 1890 og til byggeriet af Hover Forsamlingshus i 1891. I 1891 blev Kristensen sendt på delingsførerkursus i gymnastik på Askov Folkehøjskole. Herefter blev han den første frivillige gym- nastikleder i Hover for et hold på 19 karle (og 14 piger). ${ }^{13}$ Senere overtog andre unge hvervet. Kristen Kristensen beskæftigede sig dog fortsat med folkelige idræts- og oplysningsaktiviteter som folketingsmand for Venstre og som formand for Ringkøbing Amts Skytte- og Gymnastikforening fra 1914-1929. Grunden til, at Kristensen stoppede som formand i 1929, var den organisatoriske splittelse mellem skytterne og gymnasterne. ${ }^{14}$ Kristensen var pioner i en tid, hvor de folkelige idrætsaktiviteter bestod af både skydning og gymnastik og var tæt forbundet med åndelige aktiviteter ved bl.a. foredrag og politiske møder.

Mange af de første forsamlingshuse i Danmark var bygget som »aktivisthuse«, opført af en kreds af ideologiske meningsfæller med grundtvigske og venstrepolitiske overbevisninger. ${ }^{15}$ Senere blev forsamlingshusene fællesanliggender, hvor de ideologiske kampe begrænsede sig til at danne modpol til missionshuse (dog ikke i Hover) og til kampe om, hvor forsamlingshuset skulle placeres. At den politiske og den na-

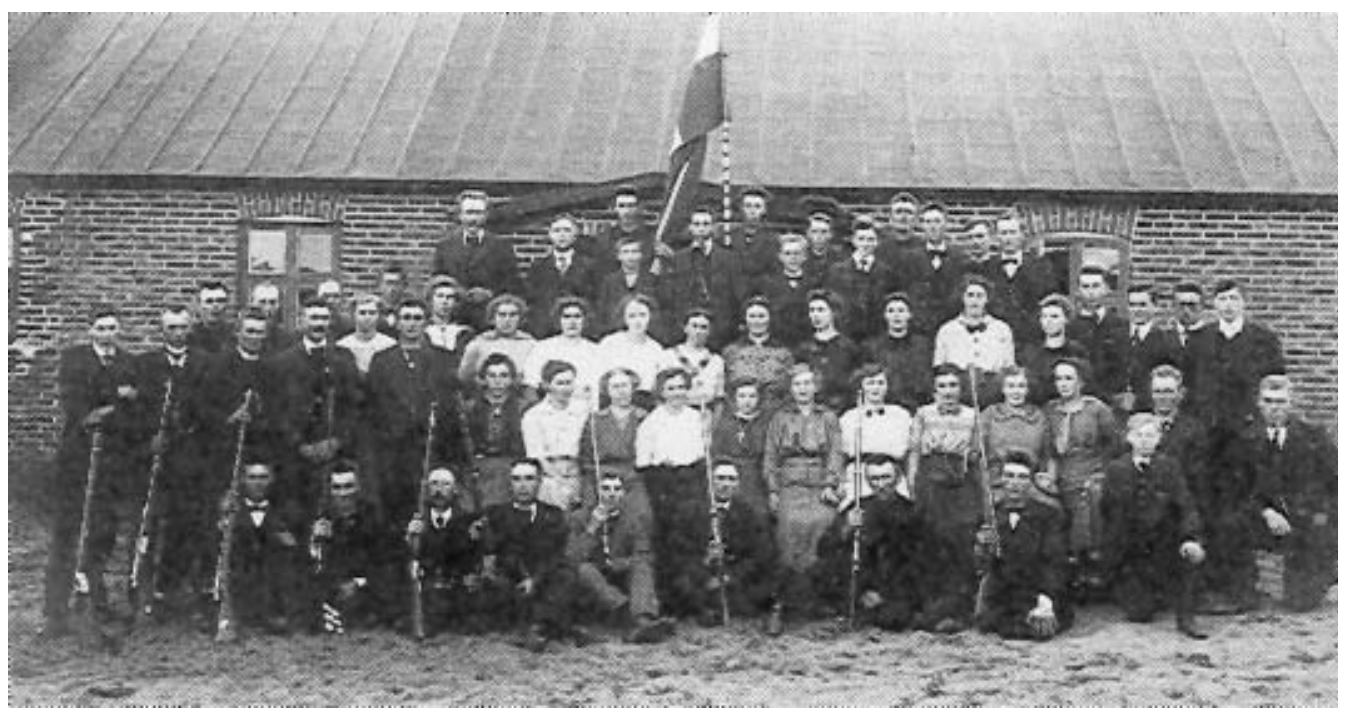

Medlemmer af Hover Skytteforening foran det første forsamlingshus. Foto: Lokalhistorisk arkiv, Hover. 
tionale organisering af folket var central ved opførelsen af det første forsamlingshus i Hover, antyder billedet nedenfor.

Sidst i 1800-tallet blev forsamlingshusene bygget forholdsvis primitivt med de forhåndenværende midler, der bestemte udformningen og mulighederne for afbenyttelse. ${ }^{16}$ Det første forsamlingshus i Hover var et langt, lavt hus tækket med tagpap, hvor højden inde i salen blev opnået ved en hvælving af loftet, der var beklædt med brædder. ${ }^{17}$ Forsamlingshuset var placeret i Hover Ådal og indrettet med en stor sal, et køkken og en lille sal, der blev brugt som skolestue i dagtimerne. I 1924 blev der bygget en ny skole i Hover by, og da et nyt forsamlingshus skulle bygges i 1927, blev det ved siden af skolen. ${ }^{18}$ Det kom til at fungere som ramme for et sekulariseret mønster af folkelige aktiviteter forstået på den måde, at forsamlingshuset ikke alene blev bygget til at rumme åndelige og legemlige aktiviteter, hvor man bekendte sig til og kæmpede for udbredelsen af en folkelig ideologi, men også til en række andre fælles og private aktiviteter i sognet. Flytningen af forsamlingshuset fra ådalen, hvor sognets gamle bøndergårde og kirken lå, til midten af Hover sogn indikerer, at forsamlingshuset var blevet et verdsligt fællesanliggende for sognets befolkning.

Forsamlingshuset udvides som sognets storstue.

Der blev oprettet en række nye forsamlingshuse rundt omkring i landet i de første årtier af 1900-tallet, efterhånden som antallet af aktiviteter deri voksede og antog en mere sammensat karakter. I Hover byggede man som mange andre steder i omegnen på det tidspunkt et nyt forsamlingshus, der kunne danne ramme om gymnastik, foredrag, dilettant, sang, folkedans, generalforsamlinger (for sognets foreninger), $m \varnothing-$ der o. lign samt et stigende antal private fe- ster. Det nye forsamlingshus i Hover rummer således en fortsættelse, men også en forandring af det mønster af folkelige aktiviteter, der var blevet anlagt i det første forsamlingshus fra 1891.

Hvor de første forsamlingshuse blev bygget som et samlingssted for datidens oppositionelle bevægelser (bl.a. skytteforeninger og andelsbevægelser) og som en reaktion mod, at staten forbød landbobefolkningens møde- og foreningsaktiviteter i almueskolerne, blev forsamlingshusene fra 1930'erne mange steder opført i tilknytning til skolerne og med støtte fra staten. ${ }^{19}$ Med andre ord blev forsamlingshusene i stigende grad apolitiske rum, der husede en række kulturelle og sociale aktiviteter for specifikke grupper eller enkeltpersoner i sognet.

I 1927 blev forsamlingshuset i Hover indrettet med et køkken, to omklædningsrum på loftet, en lille sal til møder, en stor sal med en ribbevæg og et hvælvet loft, samt en balkon på den ene gavlvæg. Omkring 1950 blev der bygget en ny indgang til forsamlingshuset. Samtidig blev den store sal udvidet, så den nu har størrelse efter målene for en badmintonbane. ${ }^{20}$ I samme ombæring blev der bygget en scene på forsamlingshusets anden endevæg, hvorunder der i kælderen blev plads til rekvisitter til dilettant såvel som til boldspil. Omkring 1970 blev der tilføjet en lavere bygning til forsamlingshuset med et redskabsrum til gymnastikredskaber m.v., toiletter og to omklædningsrum, som også benyttes i forbindelse med træning og kampe i håndbold, fodbold og volleyball på det nærliggende stadion. Udbygningen af forsamlingshuset afspejler således en udvikling i mønsteret af folkelige aktiviteter i det lille landsbysogn med gymnastikken, som den primære aktivitet, der er blevet suppleret af andre idræts- og kulturaktiviteter. 


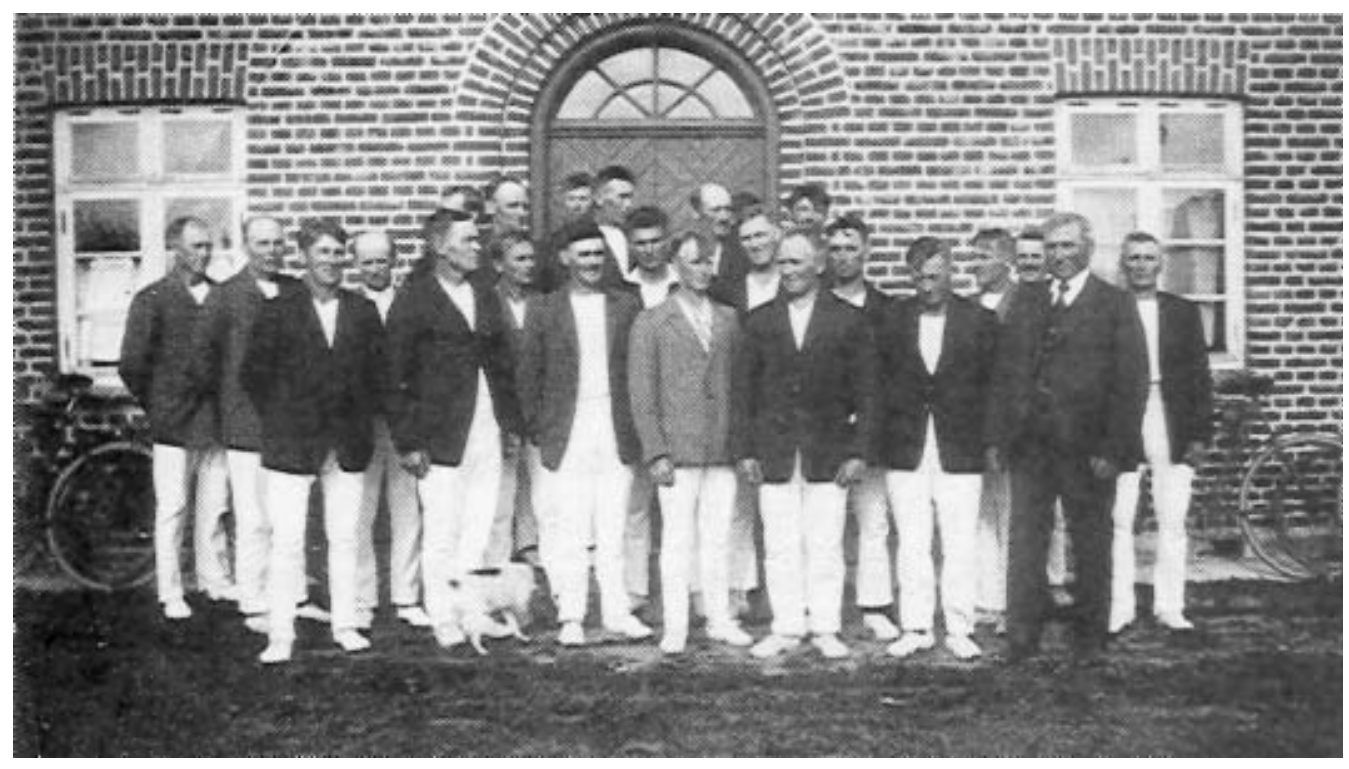

Mandshold i gymnastik foran det nybyggede forsamlingshus ved Hover Skytteforenings 40 års jubilaeum i 1930. Lederen, som er iført jakkesat, er Kristen Kristensen. Foto: Lokalhistorisk Arkiv, Hover.

\section{En gymnastikopvisning $i$ forsamlingshuset $i$ dag}

Det første og det andet forsamlingshus i Hover afspejler det arbejde og engagement, som tidligere generationer med personer som Kristen Kristensen har lagt i forsamlingshuset, hvilket på sin vis bliver videreført gennem det mønster af aktiviteter, der foregår i forsamlingshuset i dag. Med Ingolds forståelse af tidsligheden ved, at historien bliver levet i et praksislandskab, kan vi her indfange spændvidden i Hoverboernes aktiviteter eksempelvis ved den årlige gymnastikopvisning, der både viser en historisk kontinuitet med og forandringer af det folkelige. Således skal vi bl.a. se, at de politiske og nationale elementer, der var centrale ved byggeriet af det første forsamlingshus i Hover, snarere er blevet afløst af apolitiske slogans og en symbolsk brug af fanen.

$\mathrm{Nu}$ til dags involverer gymnastikopvis- ningen halvdelen af sognets beboere. Omkring 100 aktive gymnaster tager opstilling i den lille sal, og et større antal venter som tilskuere i den store sal. Kl. 19.30 slås dørene op fra den lille til den store sal. Tilskuerne rejser sig. En af sognets voksne gymnaster bærer den gamle fane ind under buerne med fare for både at ramme tilskuerne og loftet. Herefter følger gymnasterne efter størrelse og stiller sig på rækker til fanehilsen og nationalsang. Samme rækkefølge gælder ved selve opvisningen. Først viser puslinge- og børneholdene lege, bevægelser til musik og spring på redskabsbaner. Så følger det relativt lille hold af unge piger og dernæst motionsdamerne, som adskiller sig fra de unge piger i alder og et mere konservativt dragt- og Øvelsesvalg.

Til sidst giver motionsherrerne opvisning. De starter med at marchere ind, mens de synger: »Det er så godt at ha' " ryggen ret«. Herefter følger et program, der tager 
form som fritstående $\varnothing$ velser på gulv til kommando eller som $\varnothing$ velser til musik alt efter, hvilket højskoleophold den person, som leder holdet dette år, har hentet inspiration fra til programmet. I opvisningen indgår også фvelser i ribben, spring over buk samt $\varnothing$ velser på måtte. Motionsherrerne er iklædt hvide eller sorte bukser og en T-shirt, der dette år bærer trykket: »A go'er te gymnastik - Hvad gjor $d u$ «. Udover at styrke den fælles identitet blandt de vestjyske gymnaster opfordrer sentensen også andre personer til at gå til gymnastik eller til at engagere sig på anden vis. Ifølge lederen for motionsherreholdet er det bevidst, at der ikke er et anmassende spørgsmålstegn efter sentensen: Hvad gjør $d u$. Med andre ord er det nu en privat sag og ikke en fælles national sag, om folk vil engagere sig i gymnastik eller ej. Sloganet udtrykker dog et ideal, der har været gennemgående for den folkelige idræts delingsførere og ledere, som selv går forrest (fysisk og moralsk) som gode eksempler for andre. ${ }^{21}$

Efter opvisningen er der arrangeret kaffebord for de voksne i forsamlingshusets lille sal og lege for børnene i den store sal (for 15 år siden var salene fordelt omvendt). Ved kaffebordet holder repræsentanter fra alle voksenhold takketaler til lederne, mens lederne takker gymnasterne og fortæller anekdoter fra vinterens forløb. Bestyrelsen takker også og uddeler gavecheck på 300 kr. til hver leder. Kaffebordet startes og afsluttes altid med en sang. Kombinationen af sang, gymnastik og tale har i mange år været grundelementer ved folkelige gymnastikopvisninger. ${ }^{22}$ Imidlertid kan sangen og takketalerne nu kun fylde den lille sal i Hover Forsamlingshus, mens den store sal genlyder af børnenes grin og skrig i forbindelse med, at de bliver igangsat med fysiske aktiviteter. Udover at give et aktuelt bil- lede af, at idrætsforeningen prioriterer udviklingen af børn og unges kompetencer, kan fordelingen af aktiviteter i den lille sal og den store sal ses som et eksempel på, at det legemlige indtager mere plads end det åndelige ved opvisningen. Historisk set er forsamlingshuset ellers bygget til en lige vægtning af legemlige og åndelige aktiviteter, hvilket bl.a. Verner Bruhn har beskrevet med sammensætningen af begreberne plint og talerstol. ${ }^{23}$

Spørgsmålet er imidlertid, hvordan ideologien om at forbinde det åndelige og det legemlige tager form i konkrete aktiviteter: Ligger den åndelige dimension i de foredrag, sange og taler, der foregår i tilknytning til gymnastikken, eller er den situeret internt i gymnastikken? Den gymnastik, der bliver praktiseret i Hover Forsamlingshus i dag, har i høj grad baggrund i den svenske holdgymnastik. I dansk idrætshistorisk forskning er der forskellige opfattelser af denne gymnastik. Ove Korsgaard lægger vægt på den svenske gymnastiks ideologiske betydning for bondestanden og beskriver gymnastikken som åndsliggjort, mens Else Trangbæk gennem studier af $\varnothing$ velserne argumenterer for, at den svenske gymnastik medførte en opsplitning mellem opdragelsen af kroppen og sjælen, mens det kropslige og sjælelige var uadskillelige dele i den tyske gymnastik. ${ }^{24}$ Der er således ikke enighed om, hvorvidt det åndelige og legemlige var adskilte eller integrerede dele i den svenske gymnastik, og om det åndelige lå i gymnastikken eller i de tilknyttede aktiviteter. At de legemlige og åndelige aktiviteter i høj grad er blevet separeret fra hinanden (både symbolsk og materielt) vil blive illustreret ved beskrivelsen af idrætshallen nedenfor. 


\section{Halbyggeri med den industrielle vakst i 1960'erne}

Efter 1945 og især i 1960-70'erne voksede antallet af idrætshaller i Danmark. Der er flere grunde til dette halboom. ${ }^{25}$ For det første var det blevet billigere at opføre idrætshaller, da man i 1950'erne var begyndt at masseproducere nogle af elementerne. For det andet oplevede Danmark en $\varnothing$ konomisk vækst på grund af den $\emptyset$ gede industrielle produktion i 1960-70'erne. Den offentlige sektor voksede også og berørte i stigende grad områder som idræt. Staten førte en velfærdspolitik med stor offentlig støtte til idræt, der kulminerende med indførelsen af Fritidsloven i 1968, som gjorde det lovpligtigt for kommunerne at stille egnede lokaler og anlæg til rådighed bl.a. til idræt for børn og unge. Derudover kom Kommunalreformen i 1970 til at spille en ikke uvæsentlig rolle for halbyggeriet. Inden sammenlægningen i storkommuner i 1970 bevilgede en række sogne en hal til sig selv. Disse haller kan ses som en økonomisk, men også som en symbolsk oprustning af sognenes kulturelle identitet. Efter sammenlægningen i 1970 blev der desuden flere midler til idrætsbyggeri på kommunalt plan. En tredje grund til halbyggeriet var fremgangen for nye idrætsgrene som håndbold, tennis, badminton, volleyball og basketball. I 1960-70'erne blev der således bygget en række standardhaller på $22 \times 44$ meter, der fulgte de internationale mål til 1 håndboldbane, 5 badmintonbaner, 1 tennisbane, 3 volleybaner og 1 indendørs fodboldbane. ${ }^{26}$

Der er imidlertid det særligt interessante ved hallen i Højmark, at den i høj grad også er blevet bygget og udbygget til gymnastik og er opført i direkte forbindelse med et forsamlingshus. Idrætshallen illustrerer således, hvorledes mønsteret af fol- kelige aktiviteter har udviklet sig i et vestjysk landsbysogn fra 1960'erne.

\section{Idratshallen som forsamlingshusets forlangelse}

Højmarkhallen blev indviet d. 28. september 1966 til en byggepris på en halv million, der blev hjulpet på vej af en indsamling og af frivilligt arbejde udført af sognets befolkning. Andre idrætshaller på egnen, som Spjaldhallen (der er indviet d. 27. august 1966) blev oprettet efter, at foredragsforeningen var blevet nedlagt i 1963, og forsamlingshuset solgt. ${ }^{27}$ Dette var langt fra tilfældet i Højmark. Idrætshallen er her fysisk sammenbygget med Højmark Forsamlingshus, som blev bygget i 1890 og erstattet af et nyere byggeri i 1934. I forbindelse med halbyggeriet blev forsamlingshuset også påskønnet med en såkaldt »ansigtsløftning «, køkkenet blev moderniseret, omklædningsforholdene forbedret, og et cafeteria og en skydekælder blev bygget til. ${ }^{28}$

Når man læser jubilæumsskrifter og taler med nogle af de involverede i halbyggeriet, fremkommer der et gennemgående argument, nemlig at Højmarkhallen blev bygget til sognets unge, så de også om vinteren kunne dyrke gymnastik og idræt på rimelige tider og i gode rum. Strategien var således at holde de unge indenfor sognet, så de ikke tog til f.eks. Vesterhavshallen i Ringkøbing. ${ }^{29}$

Halbyggeriet skete i en periode omkring 1970, hvor den ny ungdomskultur for alvor slog igennem, og hvor der skete en svækkelse i medlemmernes følelse af tilhør til de lokale foreninger. ${ }^{30}$ Højmarkhallen blev således bygget for, at man kunne udbyde indendørs håndbold, fodbold m.v. i den lokale idrætsforening. Desuden gav idrætshallen mulighed for, at oplandets unge kunne 


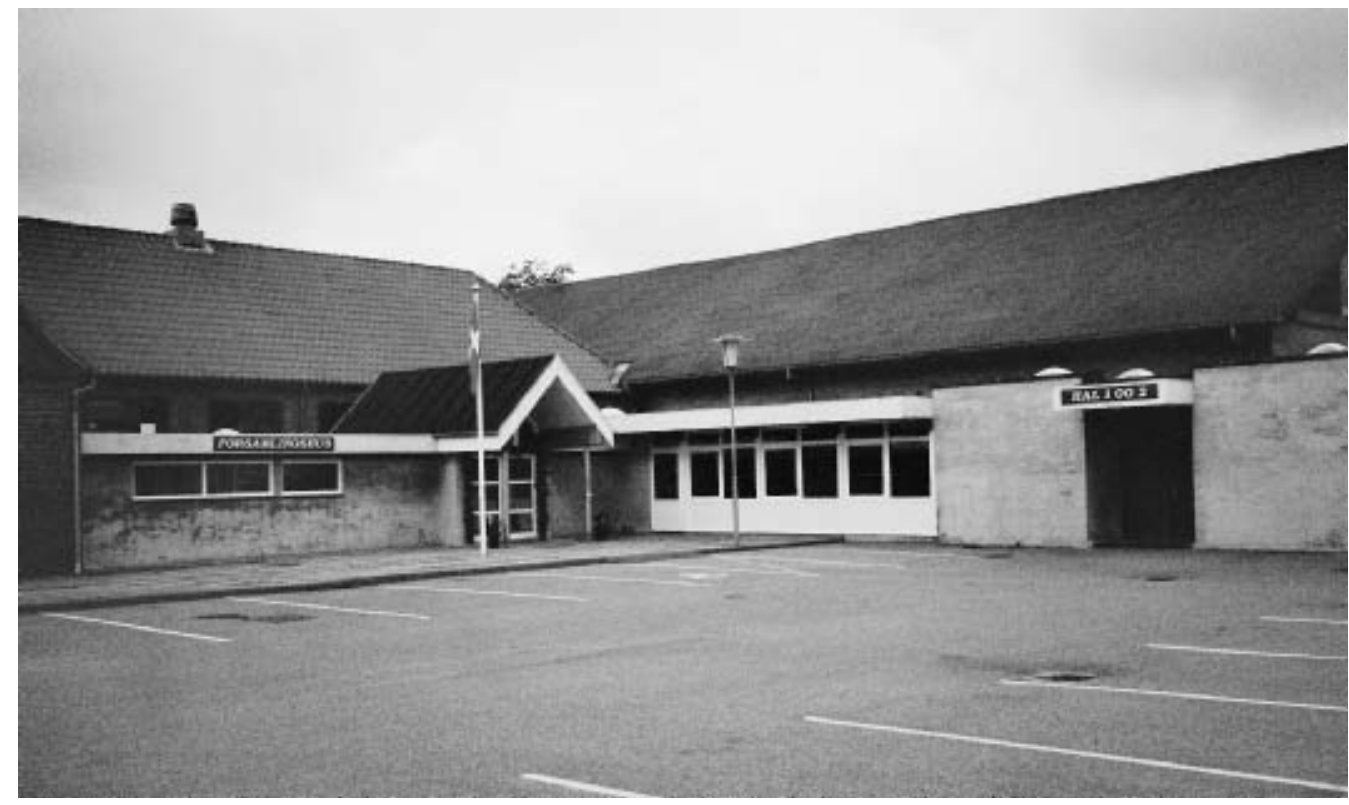

Sammenbygningen afforsamlingshuset og hallen i Højmark. Privat foto.

mødes i Højmark ved baller, som tidligere foregik rundt omkring i de forskellige sogne i forsamlingshuse, hvor der ofte ikke var spiritusudskænkning.

Halballerne blev en drønende succes. Det var noget andet end et bal i forsamlingshuset uden spiritusbevilling, hvor man var nфdt til at drikke sine medbragte bajere i kulden udenfor og skulle danse til et gammeldags orkester, der mest spillede »Klaus Jørgen«, »Hvide måge» og den slags. ${ }^{31}$

En anden grund til, at halballerne blev populære også blandt dem, der var ansvarlige for ballerne, var, at de bidrog til at afdrage dyre byggelån og til at støtte lokalforeningerne.

I over 25 år har der været arrangeret halballer i Højmark i et samarbejde mellem idrætsforeningerne i nabosognene, nemlig Ølstrup Gymnastik- og Ungdomsforening
(ØGU), Lem Boldklub (LB) og Højmark Gymnastik Forening (HGF). I dag samarbejdes der også med Ringkøbing Politi, som ikke lægger skjul på deres interesse i, at der fortsat afholdes baller i Højmarkhallen. ${ }^{32}$ Her styres begivenhederne nemlig af et stort frivilligt korps af voksne, og Højmarkballerne samler fortsat 7-800 af omegnens unge på ét sted. Hvor forsamlingshusene blev oprettet af lokale fællesskaber i det civile samfund, samarbejder de frivillige foreninger $\mathrm{i}$ idrætshallen $\mathrm{i}$ stigende grad med staten (bl.a. om ungdomsarbejdet) og henter inspiration fra markedssektoren i forbindelse med afviklingen af aktiviteter som halballer og banko.

Hvor det tidligere var folkelige foredrag, som trak fulde huse i forsamlingshuset, er det nu bankospil, der hver mandag fylder idrætshallen og giver anledning til, at folk kan føle sig som del af et lokalt fællesskab. ${ }^{33}$ Af ugeskemaet for Højmarkhallen fremgår det desuden, at enkelte timer er 
udlejet til badminton og fodbold (organiseret under naboforeningen $\varnothing \mathrm{GU})$. Håndbold (under HGF) aftager en del haltimer, men langt den største aktivitet i idrætshallen er gymnastik.

\section{Højborg for den folkelige gymnastik}

Helt fra 1966 har Højmarkhallen været ramme for Ringkøbing-Skjernegnens gymnastikhold. Det amtslige repræsentationshold - rep.-holdet, som det hedder i gymnastikkredse - var oprettet i 1965 og trænede den første sæson på Ringkøbing Skole, indtil Højmarkhallen blev bygget. ${ }^{34}$ Sidst i 1970'erne oprettede hovedkredsen også et juniorhold for 12-16årige og et aspiranthold, som er et hold for voksne gymnaster, hvortil der ikke er udtagelse (modsat rep.holdet). Sidst i 1980'erne blev navnet ændret til træningsholdet, da det ikke skulle lyde, som om gymnasterne skulle aspirere til rep.-holdet. Navneændringen afspejler samtidig den bølge af jogging, vægttræning, aerobic, workout m.v., der voksede hastigt op gennem 1980'erne, og som har medvirket til at udvide gymnastikbegrebet, så det overlapper med motionsbegrebet. ${ }^{35}$

Som jeg husker det, var der en særlig stemning over Højmarkhallen om onsdagen, hvor først juniorholdet, så træningsholdet og siden rep.-holdet trænede. Drenge og piger blev undervist på hver sin side af et gardin, som delte hallen i to, men der var rig mulighed for at stifte bekendtskab på tværs af kønnene og udvikle et stort socialt netværk undervejs i gymnastiktimerne, efterfølgende i cafeteriet, ved de årlige kaffeaftner i forsamlingshuset og ved stævner og opvisninger. Sidst i 1980'erne bestod holdene af ca. 100 juniorgymnaster, 140 på træningsholdet og ca. 40-50 udtagne gym- naster på rep.-holdet. I dag er det samlede antal noget mindre, og der har i en periode ikke været nok gymnaster til træningsholdet, som i mellemtiden endnu engang har taget navneskifte - nu til ungdomsholdet. Til gengæld har hovedkredsene oprettet et aftertrap-hold for tidligere gymnaster fra træningsholdet og rep.-holdet.

For dem, der kommer kørende til Højmarkhallen fra oplandet for at dyrke gymnastik, er der fortsat god plads afsat til parkering. Herefter kan man enten vælge indgangen til forsamlingshuset eller indgangen til hal 1 og 2 . Hal 1 ligner umiddelbart en hvilken som helst anden standardhal med plads til badminton, fodbold, håndbold, basket, volleyball etc. Det eneste, der umiddelbart afslører, at man befinder sig i Højmark og ikke i en forstad til Århus, er, at reklamerne bærer navne på lokale firmaer. Derudover bliver denne hal brudt af en ca. 10 meter lang ribbevæg, som er blevet flyttet hertil fra forsamlingshuset på den anden side af væggen. Standardiseringen af idrætshallen som et moderne sportsrum er således kun umiddelbar. ${ }^{36}$ I det øjeblik man dvæler ved detaljerne, betragter eller taler med de mennesker, der bevæger sig i rummet, bliver rummet forvandlet til et praksislandskab, hvortil der er bundet specifikke historier. I dette tilfælde fremgår det, at idrætshallen i Højmark er tæt forbundet med en folkelig gymnastikkultur.

I hal 2 bliver det endnu tydeligere, at dette idrætsrum også er bygget til gymnastik. Her er ingen reklamer på væggene. En væg er beklædt med spejle, og midt i gulvet er der sprækker, som erfarne gymnaster vil aflæse som tegn på, at der nedenunder det, der umiddelbart lader til at være et idrætshalgulv, befinder sig en springgrav.

Hal 2, som er en minihal, blev tilføjet til 
Højmarkhallen i 1992. Byggeprisen var 1 million kr., og blev holdt nede ved hjælp af frivillig arbejdskraft og private bidragydere. Eksempelvis udarbejdede de ansatte på en maskinfabrik i Højmark hydraulikken til springgraven efter deres normale arbejdstid. Efterfølgende »glemte « fabrikken at sende regningen. En fælles strategi for at bygge minihallen i Højmark var, at tilbyde faciliteter til træning og kurser og ikke mindst at opretholde institutionens anerkendelse som centrum for gymnastikken i oplandet. En af initiativtagerne beskriver målet med udbygningen således:

Forst og fremmest for at cementere vor status som gymnastikkens hфjborg, фge kursusaktiviteten og antallet af traningssamlinger til gavn for gymnastikken, for institutionen og for Hфjmarkområdet. $^{37}$

Det lykkes da også i første omgang med byggeriet af minihallen at »holde på « Ringkøbing-Skjernegnens gymnastikhold i Højmarkhallen. I denne sæson træner rep.-holdet imidlertid på en nærliggende efterskole, der netop har udvidet med lyse lokaler og gode faciliteter til springgymnastik (springgrave, stortrampoliner og fiberbane).

Med oprettelsen af nye gymnastik- og idrætsfaciliteter i lokalområdet har Højmarkhallen fået konkurrence fra andre institutioner. $^{38}$ Idrætshallerne kæmper indbyrdes om at erhverve sig økonomisk og social kapital. Den sidstnævnte kapitalform har Bourdieu defineret som »sociale forbindelser, der under bestemte forhold kan konverteres til økonomisk kapital «. ${ }^{39} \mathrm{I}$ dette tilfælde gælder kampen om at etablere sociale forbindelser bl.a. til byrådet og til amtets gymnastikudvalg, der kan sikre den $\emptyset$ konomiske indtjening ved at placere en række arrangementer i Højmark.
Idrætshallen er et noget mere kulturelt differentieret praksislandskab til gymnastik, idræt, bankospil og baller set i sammenligning med de forsamlingshuse, der blev oprettet omkring år 1900 i det samme område. Det åndelige er i højere grad eksternaliseret fra idrætten $\mathrm{i}$ hallen og bevaret $\mathrm{i}$ det tilhørende forsamlingshus, hvor der fra 1890 har været indsat en marmorplade i gavlen med ordene: »Lad Haand og Aand Gaa Haand i Haand. Det baade skal dem Begge«. Idealet er med andre ord, at det gavner mennesket, når det åndelige og legemlige er tæt relaterede. Det er den grundtvigske opfattelse af, at mennesket består af både ånd og støv, der idealiseres her. ${ }^{40}$

I Højmark Forsamlingshus kan man desuden finde en række sentenser, der fremstår som et sæt af åndelige leveregler. En del inskriptioner udtrykker en særlig vestjysk arbejdsetik med engagement, handleevne og flid: »Lev i dit vark, mens det фves, Hvad du gфr i dag - bør ej opsattes til i morgen, Aldrig fardig, altid på vej, Hvert minut du bortфdsler, er for evigt tabt, At vente og håbe, gфr mangen til tåbe, At mene det rette er intet, at kampe for det rette er alt."Andre inskriptioner appellerer til en udvikling af respekt for sandhed, renhed, ære og ydmyghed over for sit eget liv og andres: »Rank ryggen og tal sandhed, Ofte for venskabet, altid for sandheden, For den rene er alting rent, Mands ord, mands are, Brug livet, men misbrug det ej, Let er den byrde, en anden borer. « Derudover afspejler nogle af inskriptionerne det folkelige oplysningsideal om, at mennesket skal gennemgå en almen dannelse: „Giv agt på hvad der siges - spфrg ikke om, hvem der siger det, Lyt toenk, men handl så, Gode ord er guld vard, Alt hvad er ret, er bedre end hvad klogt kun er. «Disse sætninger står som idealer fra tiden sidst i 1800-tallet, mens der i dag ikke i samme grad følger et sæt af åndelige leve- 
regler med det at deltage i folkelige idrætsaktiviteter.

I Højmark indgår idrætshallen dog i den samme bygning og dermed i den samme materielle og symbolske orden som forsamlingshuset. På trods af ordenes magt antyder tilføjelsen af minihallen (med en springgrav), hvordan det folkelige idrætsbegreb er under forandring på en måde, hvor der er større fokus på det materielle, det legemlige og på den personlige dygtiggørelse. Disse og andre udviklingstendenser afspejler sig ligeledes $i$ et af de nyeste eksempler på rum bygget til den folkelige gymnastik og idræt, nemlig det multiaktivitetshus, som beskrives nedenfor.

\section{Multiaktivitetshuset}

Efter det såkaldte halboom i 1960-70'erne fulgte en periode med stilstand i idrætsbyggeriet i Danmark, bl.a. på grund af en stram økonomi i kommunerne, ændringer i idrætsmønsteret, mindre kommunal interesse for idrætsbyggeri og vanskeligheder ved at starte et idrætsbyggeri på frivilligt initiativ på grund af $\varnothing$ gede krav til anlæg og byggeri samt professionalisering af idrætsbyggeriet. ${ }^{41}$

I stedet blev der i 1980'erne opført et stigende antal idræts- og motionsfaciliteter af private investorer. Markedet var således på vej til at overtage dele af det idrætsbyggeri, der historisk set var udviklet af lokale fællesskaber i det civile samfund. En dansk civilsamfundstradition, som i høj grad er blevet støttet af staten.

Først midt i 1990'erne tog staten og idrætsorganisationerne initiativ til en nyudvikling af idrætsbyggeriet i Danmark. En central aktør i denne udvikling er Lokaleog Anlægsfonden, der blev oprettet ved lov i 1994 som en fors $\varnothing$ gs- og udviklingsfond, hvor nytænkning og eksperimente- rende byggeri sættes højt. Fonden startede med en egenkapital på 140 millioner kroner, indskudt af Danmarks Idræts-Forbund, Danske Gymnastik- og Idrætsforeninger, Dansk Firmaidrætsforbund og Dansk Ungdoms Fællesråd, og hvert år modtager fonden 60-70 millioner $\mathrm{kr}$. af overskuddet fra Tipstjenesten. ${ }^{42}$ Lokale- og Anlægsfonden har været en aktiv part i formgivningen af bl.a. DGI-byen i København og DGI-huset i Århus.

\section{Fra industrielt togvarksted til postindustrielt kropsvarksted}

DGI-huset er oprettet i nogle af de bygninger, der tidligere husede en af de historisk set mest betydningsfulde arbejdspladser i Århus, nemlig Centralværkstedet, som voksede frem med etableringen af de første jernbaner og industrialiseringen $i$ sidste halvdel af 1800-tallet. Omkring år 1900 arbejdede 800 mand i Centralværkstedet, og $i$ årene efter 2. verdenskrig kulminerede arbejdsstyrken med 1800 mand. ${ }^{43}$ Dampmaskinen var symbolet på fremdrift og ekspansion indenfor industrien, og de samme idealer afspejlede sig i udviklingen af sporten i Århus. ${ }^{44}$ En historisk sammenligning af togværkstedet og DGI-huset udpeger en række interessante perspektiver i den kropskulturelle udvikling fra industrisamfundet, hvor arbejderne udførte hårdt arbejde, som ofte var farligt og nedslidende for kroppen, til det postindustrielle samfund, hvor den enkelte må dyrke fysisk aktivitet som kompensation for stillesiddende arbejde og som værn mod velfærdssygdomme.

I sommeren 2003 færdiggjorde man ombygningen fra DSB's Vognrevisionsværksted til DGI-huset. Idéen til byggeriet havde imidlertid været længe undervejs. DGIÅrhusegnen og andre idrætsorganisationer 
og institutioner i byen (ikke mindst Katedralskolen) udviklede idéen om at etablere idrætsfaciliteter i de efterhånden tomme bygninger, der havde huset Centralværkstedet. ${ }^{45}$ Midt i 1990'erne blev der ved en række møder og konferencer sat fokus på de manglende idrætsfaciliteter i Århus « midtby. Ved vedtagelsen af Århus Kommunes Idrætspolitik i 1997 var der i mellemtiden blevet skrevet en hensigtserklæring og en specifik forslagsgiver ind i de Konkrete prioriteringer med følgende ordlyd om, at kommunen vil: »støtte etablering af en midtbyhal. Der foreligger et forslag fra DGI-Århusegnen. «46

At DGI-Århusegnen blev bygherrer for det nye idrætsbyggeri i midtbyen skyldtes for det første, at de var i stand til at overtale Århus Kommune til med et stort bel $\varnothing b$ at støtte dette multiaktivitetshus, som kunne give rum til idræts- og kulturaktiviteter $\mathrm{i}$ midtbyen. For det andet gik DGI-Århusegnens idéer fint i spænd med Lokale- og Anlægsfondens strategier om at støtte eksperimenterende idrætsbyggeri. For det tredje viste DGI på landsplan interesse for (og havde økonomi til) at profilere den folkelige idrætsideologi og udvikle foreningerne i storbyen ${ }^{47}$. De tre grunde afspejler sig i følgende uddrag fra den første præsentationsfolder om DGI-huset.

et topmoderne multiaktivitetshus med haller og rum til idrcets- og kulturaktiviteter samt faciliteter til kurser, møder og administration... DGI-Århusegnen фnsker med huset at etablere et eksperimenterende og nyskabende idratsmilj $\phi$, der drives i overensstemmelse med DGIÅrhusegnens formål og som sådan medvirker til at sikre og synligg $\phi r e$ foreningens vardier. ${ }^{48}$

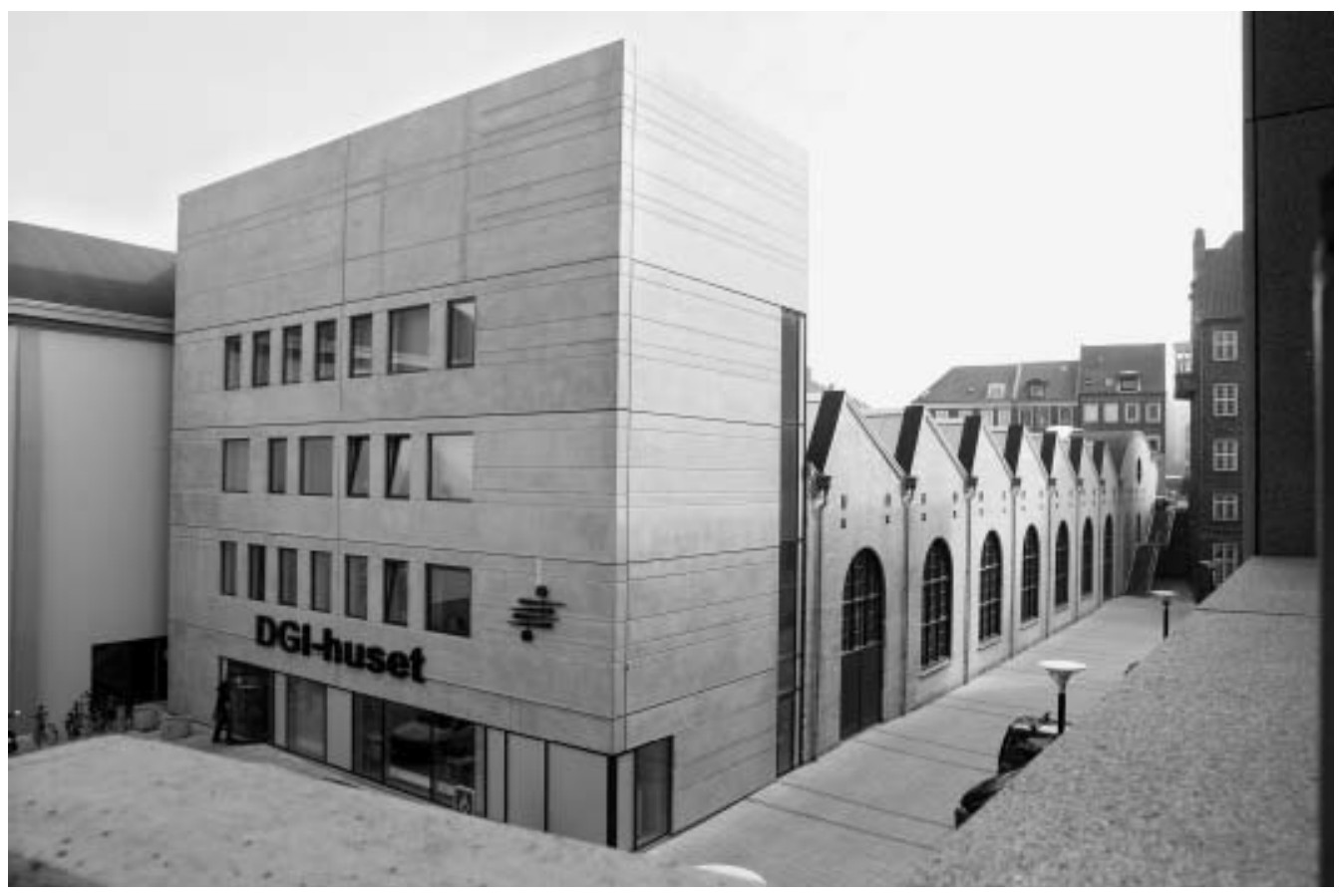

DGI-huset set fra Bruuns Galleri. Foto: Behrend Fotografi I/S. 


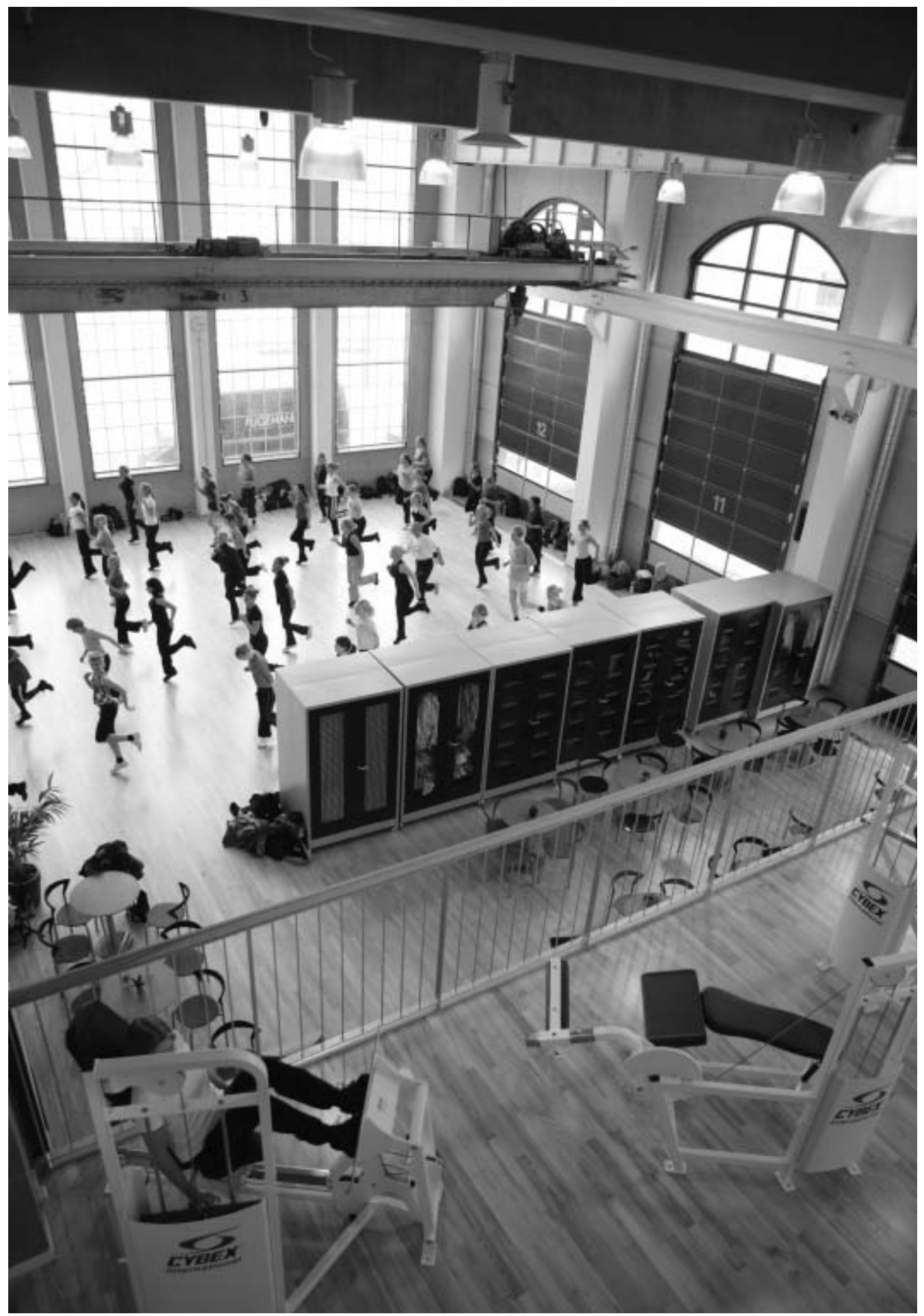

Styrketraningsområdet med udsigt ned i Hal D. Foto: Behrend Fotografi I/S. 
At de ovenstående idealer for DGI-huset hænger tæt sammen med de partnere, som har støttet projektet, fremgår af, at byggeprisen på 47,5 millioner kr. blev finansieret med 20,1 mio. kr. fra Århus Kommune, 6 mio. kr. i et rentefrit lån over 5 år fra Århus Amt, 7 mio. kr. fra Lokale- og Anlægsfonden, 13 mio. kr. fra DGI på landsplan og 1,4 mio. kr. fra DGI-Århusegnen.

\section{Folkelig idrcet og motion $i$ midtbyen}

DGI-huset er placeret bag ved banegården som del af et nyt erhvervs- og fritidsområde i midtbyen. Går man ud ad bagindgangen fra det nye butikscenter Bruuns Galleri, ligger DGI-huset for fødderne af en. En administrationsbygning $i$ grå beton er tilføjet foran de gamle fredede lokomotivhaller, der i deres ydre form fremstår, som da de blev brugt til at reparere togvogne.

Indenfor befinder man sig straks midt i et aktivitetshus. Foran ligger de to boldspilshaller, der er henholdsvis $15 \times 30$ meter og $18 \times 42$ meter. De passer således ikke til de internationale standarder for boldbaner. Til venstre ligger cafeen lidt klemt inde ved siden af Hal D, hvor der ofte foregår fitnessog aerobicundervisning under de gamle fredede kraner, som tidligere blev brugt til at bugsere togvogne. For at komme videre $\mathrm{i}$ huset må man bevæge sig op gennem det forreste trappetårn. På 1. sal kommer man ud midt $i$ et styrketræningsområde og befinder sig omgivet af personer, der er i gang med at løfte vægte eller træne i maskinerne med frit udsyn og fuld eksponering $i$ huset. Videre hen langs gangbroen har man boldspilshallerne under sig og springhallen foran sig samt den 30 meter høje indendørs klatrevæg til den ene side. Fremme i den modsatte ende af DGI-huset kan man be- væge sig ned ad trappen til omklædningsrummene eller helt op under taget, hvor en rytmehal er skudt ind ovenpå den ene boldspilshal. Videre finder man de eneste aflukkede rum i huset nemlig et mindre aktivitetslokale, samt mødelokaler og kontorer for DGI-Århusegnen og DGI-huset.

Multiaktivitetshuset anvendes af foreninger, institutioner og de såkaldt uorganiserede. Den sidste gruppe har DGI-huset satset særligt på som brugere ved hjælp af et udbud af aktiviteter som styrketræning, aerobic, pilates, powerdance, fodbold, badminton, klatring, stavgang etc. under navnet Clip'N'Fit. Tilmeldingen hertil foregår fra gang til gang ved hjælp af et elektronisk klippekort. DGI-huset har desuden involveret sig i en række projekter i løbet af sit første leveår: Århus festuge, gymnastikskoler, julehop for børn, firmaarrangementer, En dag på Hogwarts (i samarbejde med Bruuns Galleri, Bruuns Gade Foreningen og Centralværkstedet) og sundhedsugen (i samarbejde med Århus Amt og i forbindelse med Sundhedsstyrelsens kampagne: $30 \mathrm{mi}$ nutter om dagen). Med sådanne projekter går DGI-huset direkte i samarbejde med markedet og staten om motions- og sundhedsaktiviteter. ${ }^{49}$ Gymnastikken står dog stadig som den primære idrætsaktivitet i huset bl.a. ved, at en stor del af de bedste tider i hallerne udlejes til DGI-Århusegnens junior-, aspirant- og rep. -hold og gymnastikhold fra byens lokalforeninger.

Overskriften på DGI-husets hjemmeside er: »Byens nye motionsmekka - for alle og for enhver. " Begrebet »motionsmekka« indikerer, at dette er et samlingssted, som man retter sin opmærksomhed mod, har tiltro til og valfarter til. Udtrykket »for alle og for enhver « signalerer, at der både er plads til alle i et stort fællesskab og til enhver enkeltperson. DGI-huset er et mekka for alle dem, som gerne vil dyrke motion. 
Set i sammenligning med idrætshallen er der her bl.a. med Clip'N'Fit-aktiviteterne for alvor givet plads til det legemlige og til individuel motionsudøvelse.

Med DGI-huset har formålet (som nævnt ikke uden politiske undertoner) været at sikre og synliggøre den folkelige idræt i midtbyen. Den aktuelle udfordring for DGI-huset er imidlertid at tydeliggøre, hvori det folkelige består eksempelvis ved konceptet Clip'N'Fit i forhold til aerobicog styrketræningsaktiviteter $i$ et af byens fitnesscentre? For mig at se, nærmer DGIhusets idrætsbegreb sig statens motionsbegreb og markedets fitnessbegreb ved et udbud af projekter og aktiviteter, som retter sig mod institutioner og enkeltpersoner.

Samtidig er der en lang række foreningsfolk engageret i DGI-huset, der kan ses som en inspirator for eller som en konkurrent til de lokale idrætsforeninger. Foreløbig ser det ud til, at de lokalforeninger, som bruger DGI-huset, oplever en fremgang - bedømt på antallet af medlemmer og aktivitetsniveauet. ${ }^{50}$ Således er det stadig relevant at tale om et mønster af folkelige aktiviteter i multiaktivitetshuset - dog i en udvidet forstand - idet der indgår både gymnastik-, idræts- og motionsaktiviteter samt sundhedsprojekter i oplysningen af folket.

\section{Afslutning}

Afslutningsvis følger her en overordnet sammenligning af, hvilke opfattelser af folket og af mennesket (som henholdsvis ånd og legeme eller krop og fornuft), der kommer til udtryk i de udvalgte idrætsfaciliteter.

I denne historiske komparation, der umiddelbart krydser tid og rum, er det nyttigt at opløse enhedsopfattelsen af den folkelige idræt for at pege på de forskellige aspekter af begrebet, der primært kommer til udtryk henholdsvis i forsamlingshuset, idrætshallen og multiaktivitetshuset.

I sin doktordisputats Kampen om folket henviser Ove Korsgaard til, at grækerne havde tre forskellige ord for folket, nemlig demos, som refererer til en politisk forståelse af begrebet folk, ethnos, der dækker over en etnisk eller kulturel forståelse, og pléthos, der står for en social forståelse af folket som mængde. ${ }^{51}$ Selv om disse tre begreber samlet bidrager til en kompleks forståelse af aspekter ved dannelsen af et folk, vil jeg skelne mellem begreberne og det på en lidt anden måde, end den Korsgaard udfolder i sin bog.

Det er især den politiske forståelse af folket (som demos), der kommer til udtryk ved byggeriet af de første forsamlingshuse som aktivisthuse. Sidst i 1800-tallet blev forsamlingshusene bl.a. oprettet på grund af Højreregeringens regulativer mod møde- og foreningsaktiviteter i landsbyskolernes lokaler og som steder for politiske m $\varnothing$ der, samt skytte- og gymnastikaktiviteter.

Den kulturelle forståelse af folket (som ethnos) er i højere grad central for at forstå, hvordan forsamlingshuset op gennem 1900-tallet bliver en del af det kulturelle liv i sognet med et sammensat mønster af idræts-, møde- og festaktiviteter. Herigennem fremstår lokalbefolkningen som et folk, der definerer sig selv som del af den samme gruppe og som forskellige fra andre. Denne etniske og kulturelle forståelse af folket kan siges at være central for byggeriet af Højmarkhallen, hvor man forsøger at undgå, at sognets unge tiltrækkes af byens idrætsanlæg og fritidsudbud. Ved nogle af aktiviteterne i hallen indgår nabosognenes idrætsforeninger og oplandets gymnastikinteresserede også i folket.

I multiaktivitetshuset viser der sig i højere grad en social forståelse af folket (som 
pléthos) - som en mængde, der skal aktiveres og engageres i idræt og motion. Her bekender institutionen sig i højere grad, end det tidligere har været tilfældet indenfor den folkelige idræt, til et socialt arbejde med at udbrede den folkelige gymnastik og idræt i midtbyen. Det sker i praksis ved at igangsætte projekter for overvægtige børn, studerende, fysisk inaktive voksne, seniorer etc. Et socialt arbejde, som er blandet med markedsorienteret projektarbejde. Hvilke projekter man udbyder afhænger bl.a. af, hvilken efterspørgsel og hvilke støttemuligheder der er for de forskellige målgrupper. Folket består således her af en række sociale grupper, der søges igangsat og oplyst i DGI-huset.

Det efterlader spørgsmålet, om der med udviklingen af det postmoderne samfund er sket et historisk brud, så det ikke længere er relevant at anvende folkelighedsbegrebet, men derimod at tale om specifikke målgrupper. Med Ingolds processuelle tilgang har min analyse af idrætsfaciliteter som kulturhistoriske landskaber imidlertid vist, hvordan et mønster af folkelige aktiviteter har udviklet sig med både historisk kontinuitet og forandring.

Beskrivelserne af de tre idrætsbygninger giver desuden et indblik i, hvordan den folkelige gymnastik og idræt har udviklet sig med idealer om at forene forskellige dualis- mer. Ifølge en kristen, dualistisk opfattelse består mennesket af et dødeligt legeme og af en levende $»$ ånd $\ll .{ }^{52}$ Historisk set er det denne kristne dualisme mellem det åndelige og legemlige, som den folkelige idrætsideologi søger at forene..$^{53}$ Dette ideal, har vi set, sætter sit præg på aktiviteterne i forsamlingshuset (henholdsvis i den lille og store sal) samt i idrætshallen, som er sammenbygget med og indgår i den samme symbolske og materielle orden som et forsamlingshus.

Med den videnskabelige og teknologiske udvikling har der også udviklet sig en anden dualistisk opfattelse af, at mennesket består af en mekanisk »krop«, der adskiller sig fra en suveræn »fornuft«, som skal føre mennesket fra uvidenhed til frigørelse (i dette tilfælde fra overvægt, livsstilssygdomme etc.). ${ }^{54}$ For mig at se, er det ikke den kristne, men den videnskabelige dualisme, som DGI-huset søger at forene, når man kombinerer fysiologisk viden om effektive træningsformer for kroppen (ved aerobic, fitness etc.) med projekter, der bl.a. i samarbejde med Sundhedsudvalget i Århus Amt forsøger at formidle en viden til befolkningen, så de kan ændre deres livsstil og vaner. ${ }^{55}$

Nedenfor har jeg skitseret de overordnede forskelle mellem, hvilke opfattelser af mennesket og folket, der primært kommer

\begin{tabular}{l|l|l|l} 
& Mønster af aktiviteter & Begreber for mennesket & Opfattelse af folket \\
\hline Forsamlingshuset & $\begin{array}{l}\text { Skydning, gymnastik, } \\
\text { foredrag og politiske } \\
\text { møder }\end{array}$ & $\begin{array}{l}\text { Det åndelige i nær } \\
\text { forbindelse med det } \\
\text { legemlige }\end{array}$ & Demos, politisk \\
\hline Idrætshallen & $\begin{array}{l}\text { Gymnastik, idræt (især } \\
\text { håndbold), bankospil } \\
\text { og baller }\end{array}$ & $\begin{array}{l}\text { And og legeme hånd } \\
\text { i hånd, men mere } \\
\text { 'plads' til legemet }\end{array}$ & Ethnos, kulturelt \\
\hline Multiaktivitetshuset & $\begin{array}{l}\text { Gymnastik, idræt og } \\
\text { motion (fra styrke- } \\
\text { træning til stavgang) }\end{array}$ & Krop og fornuft & Pléthos, socialt \\
\hline
\end{tabular}


til udtryk, når man studerer det mønster af aktiviteter, som udfolder sig henholdsvis i forsamlingshuset, idrætshallen og multiaktivitetshuset.

Beskrivelserne af de udvalgte idrætsfaciliteter giver et begrænset, men konkret indblik i generelle træk ved, hvordan opfattelsen af folket og mennesket har ændret sig gennem det sidste århundrede. Samtidig viser analysen en historisk kontinuitet ved beskrivelserne af det mønster af folkelige aktiviteter, der fortsat bliver levet i rummene. Med andre ord giver objektiveringer af den folkelige idrætskultur i form af forsamlingshuse, idrætshaller og multiaktivitetshuse adgang til at se glimt af, hvordan idrætshistorien har udviklet sig tilbage fra dem, som har frembragt stederne, selv om vi ikke har direkte adgang til at observere den praksis, der foregik dengang. ${ }^{56}$

\section{Noter}

1 Hans Lyngsgård har som en af de første i Danmark udført en syntesedannende analyse af gymnastikkens, sportens og badets rum som idrætsrum, der betragtes i et arkitekturteoretisk og arkitekturhistorisk perspektiv (jf. Lyngsgård 1990).

2 I anden sammenhæng har jeg beskrevet, hvordan folkelighedsbegrebet har fået karakter som et støvet begreb i dag (Agergaard 2004a). Det er ikke begrebsmæssige diskussioner af, hvordan det folkelige skal defineres, som jeg vil se på i denne artikel, men derimod de specifikke opfattelser af folket, som kommer til udtryk i praksis i konkrete idrætsrum.

3 I historiske studier beskrives 1957 ofte som årstallet for den anden industrielle revolution i Danmark og for overgangen fra et overvejende landbrugsland til et industriland (Busck \& Poulsen 2000: 359). Overgangen til det postindustrielle samfund er der ikke samme enighed om. I stedet for at fokusere på bruddet mellem de forskellige samfundsformer er det interessante i dette tilfælde at betragte den historiske kontinuitet ved, at den folkelige idræt overleveres og forandres gennem de tre samfundsformer.

4 Møller (1997) s. 126.

5 Agergaard (2004b) s. 86f.

6 Tuan (1974/90).

7 Kayser Nielsen (1994) s. 126.

8 Ingold (2000) s. 189f.

9 Jf. Tangen (2003).

10 Ottesen \& Ibsen (2000) s. 11.

11 Højmark forsamlingshus blev oprettet i 1890 (Lambæk 1982 s. 42), mens Ølstrup forsamlingshus er fra 1901 (Susgaard 1990 s. 254).

12 Kaae (1967) s. 260.

13 Der foreligger ikke oplysninger om, hvorvidt det også var Kristen Kristensen, som ledede kvinde-

holdet. Højst sandsynligt har det nærmere været en lærerinde ved Hover Skole.

14 Jf. 75-års jubilæumsskriftet: Ringkфbing Amts Skytteforening 1878-1928, 1928-1953 s. 26.

15 Forsamlingshusudvalget (1979) s. 10.

16 Lyngsgård (1990) s. 24.

17 Kaae (1967) s. 259.

18 Ibid. s. 215. Skolen kunne således allerede fra 1927 benytte forsamlingshuset som gymnastiksal. Med folkeskoleloven i 1937 blev det lovpligtigt, at der ved alle skoler, som underviste børn over 12 år, skulle »indrettes en gymnastiksal med tilhørende omkladningsvarelser og badeindretning." (Ottesen \& Ibsen 2000 s. 14).

19 Ibid. (2000) s. 12-13.

20 Til sammenligning var de første forsamlingshuse, der blev bygget sidst i 1800-tallet, oftest $8 \times 16$ meter, hvilket gav plads til opstilling af et gymnastikhold på 36 karle eller piger (ibid. s. 13).

21 Ordene på motionsherrernes T-shirt trækker perspektiver tilbage til uddannelsen af delingsførere i gymnastik, der har fundet sted på en række højskoler fra sidst i 1800-tallet. Idealet for delingsføreren var at være en foregangsmand, som ikke alene var dygtig til at lede gymnastik, men også gik forrest i moralske sager. Den moralske forpligtelse til at gå forrest er bl.a. blevet fremhævet for ledere uddannet ved Gymnastikhøjskolen ved Viborg af forstander Mads Nielsen (Rasmussen 2001 s. 101).

22 I forbindelse med oprindelsesmyten for den folkelige idrætshistorie, nemlig indførelsen af den svenske gymnastik på Vallekilde Højskole d. 25/2 1884, skriver Ove Korsgaard, at de tre komponenter: sang, tale og gymnastik blev grundelementerne i enhver gymnastikfest på landet de næste 75 år (Korsgaard 1982/97 s. 84). 
23 Bruhn (1979).

24 Korsgaard (1982/97) s. 85 og Trangbæk (1987) s. $200 f$.

25 Et halboom, da der fra midten af 1960'erne til 1980'erne blev opført ca. 1000 idrætshaller i Danmark. Et antal, som svarer til det antal af forsamlingshuse, der blev opført sidst i 1800-tallet. Årsagerne til dette halboom er bl.a. beskrevet i Ottesen \& Ibsen (2000), Lyngsgård (1990) og Kayser Nielsen (1995).

26 Lyngsgård (1990) s. 100.

27 Kayser Nielsen (1995) s. 97.

28 Lambæk (1982) s. 48.

29 Ibid. s. 47.

30 Kayser Nielsen (1995) s. 99.

31 Ibid. s. 98.

32 Jf. Interview med Kurt Johansen, som er tidligere formand for bestyrelsen af Højmarkhallen.

33 Motiverne for at spille banko varierer, men ifølge Åke Daun indgår der både spænding, underholdning og samvær i spillet (Daun 1977). Spændingen består i, at deltageren har sit eget og andres held og uheld tæt inde på livet, underholdningen udfolder sig bl.a. ved, at alle umiddelbart kan deltage på afslappet vis uanset alder og uddannelse, og fællesskabet ligger i den fælles beskæftigelse, småsnakken og tætte placering ved bordene.

34 Jf. Interview med Knud Tarpgaard, som var deltager på Ringkøbing-Skjernegnens rep.-hold, da det startede i 1965, og den første mandlige leder for aspirantholdet i 1977.

35 Larsen (2003) s. 38.

36 Med inspiration fra den engelske kulturgeograf Edward Relph har John Bale med begrebet placelessness beskrevet standardiseringen af moderne sportslandskaber bl.a. fodboldstadions, svømmeog løbebaner (Bale 1994 s. 100f).

37 Johansen (1990) s. 57.

38 Konkurrencen skyldes bl.a. den store halkapacitet i Ringkøbing Kommune, og at der særligt er et stort antal haller i området omkring Højmark, nemlig i Lem, Dejbjerglund, Velling og ved de to gymnasier i Ringkøbing.

39 Bourdieu (1986) s. 243 (min oversættelse).

40 Jensen (1990) s. 50.

41 Ottesen \& Ibsen (2000) s. 21f.

42 Ibid. s. 23.
43 Cordes (1993) s.19.

44 Jf. Nielsen (1990).

45 Jf. Interview med Flemming Mølgaard, en af initiativtagerne til DGI-huset og nu forretningsfører i DGI-Århusegnen.

46 Århus Kommunes Idrætspolitik vedtaget af byrådet d. 10/9 1997.

47 Planerne om at bygge DGI-huset i Århus udviklede sig samtidig med, at DGI-byen i København var under opførelse. 1. etape af DGI-byen stod færdig i december 1997.

48 Præsentationsfolder for DGI-huset.

49 Med andre ord indgår DGI-huset i et partnerskab med markedet og staten, mens DGI tidligere har været forbundet i et slægtskab til højskoler, ungdomsforeninger m.fl. som relaterede institutioner i det civile samfund.

50 Aktivitetsudbuddet er bl.a. vokset for unge i flere af de foreninger, der anvender DGI-huset. Derudover har der været medlemsfremgang i foreningerne og på DGI-Århusegnens amtshold (oplyst af Flemming Mølgaard, forretningsfører i DGIÅrhusegnen).

51 Korsgaard (2004) s. 13-14.

52 Eichberg (1990a) s. 29f.

53 Der er en lang række nuancer i dette generelle træk, som ikke kan behandles her. Inden for den folkelige idrætshistorie bliver der ofte refereret til Grundtvigs formuleringer om det hele menneske, som et opgør med den sorte skole og et argument for, at der er en dyb inderlig sammenhæng mellem det legemlige og sjælelige (Korsgaard 1982/97 s. 100f.).

54 Liedman (2000) s. 135.

55 Jf. Interview med Troels Knudsen, direktør for DGI-huset.

56 »Menneskets ekspressivitet kan objektiveres, og det vil sige, at den manifesterer sig $i$ den menneskelige aktivitets produkter, som er tilgangelige for både frembringere og for andre som del af en falles verden. Sådanne objektiveringer registrerer mere eller mindre pracist, de subjektive processer hos dem, der har frembragt dem, og gфr det muligt at forstå disse processer, selv om man ikke befinder sig $i$ en ansigt- til ansigt situation, hvor de kan opfattes direkte." (Berger \& Luckmann 1966/2000 s. 50). 


\section{Litteraturliste}

S. Agergaard, »Folkelighed; fra beskyttet diskurs til flydende betegner? «I: Christensen, M. K. \& Wickman, G. (eds): Krop, Kompetence og andre фrehangere. Aktuelle begreber inden for paedagogik og sundhed. (København 2004a) s. 31-46.

S. Agergaard, At viderefore traditionerne. En etnografisk komparativ analyse af to danske idratsuddannelser for folkelige ledere og elitetranere. (Ph.d.-afhandling. Frederiksberg: Multivers Academic, 2004b).

J. Bale, Landscapes of Modern Sport. (Leicester/London/New York 1994).

P.L. Berger \& T. Luckmann, Den samfundsskabte virkelighed. En videnssociologisk afhandling (Viborg 1966/2000).

P. Bourdieu, »The Forms of Capital.« I: Richardson, J. G. (ed): Handbook of Theory and Research for the Sociology of Education. (New York/Westport/Connecticut/ London 1986). s. 241-260.

V. Bruhn, Plint og talerstol: trak af gymnastik- og ungdomsforeningernes historie i Ribe Amt. Esbjerg: Ribe Amts Gymnastik- og Ungdomsforeninger

S. Busck \& H. Poulsen (eds), Danmarks historie $i$ grundtrak. (Århus 2000).

S. Cordes, »Fyrhuls-Atleten, Congo-Pedersen og Bertel Langskæg. «I: Ud og Se nr. 10 (1993), s. 18-21.

Å. Daun, Bingospelare. En samhälls- och kulturundersökning. (Kristianstad 1977).

H. Eichberg, »Krop, legeme - og hvad ellers. Overvejelser over den tredje krop.« I: Centring nr. 25 (Slagelse 1990), s. 24-40.

Forsamlingshusudvalget, Forsamlingshuse på landet: en redegørelse (Ministeriet for kulturelle anliggender 1979).

T. Ingold, The Perception of the Environment. Essays in livelihood, dwelling and skill (London/New York 2000).

N. J. Jensen, »Hånd og ånd « I: Højmark Forsamlingshus 1890-1990 (Højmark 1990), s. 49-52.

K. Johansen, »Jubilæumsbetragtninger« I: Højmark Forsamlingshus 1890-1990 (Højmark 1990), s. 5558.

N. Kayser Nielsen, Stil \& Ballade - modstridende tendenser og paradokser i 1980'ernes kropskultur (Odense 1994).

N. Kayser Nielsen, »Aktiviteter - idræt i hverdag og fest « og »Klublivet i huse og haller - tre lokalområder.«I: Trangbæk E. et al. (red): Dansk Idratsliv 2: Velfard og fritid 1940-96 (Brøndby 1995), s. 79-99.

O. Korsgaard, Kampen om kroppen. Dansk idrcets historie gennem 200 år (København 1982/97).

O. Korsgaard, Kampen om folket. Et dannelsesperspektiv på dansk historie gennem 500 år (København 2004).

A. Kaae, Hover. Sognet ved åen (Udgivet af Hover Sogneråd 1967).

M. Lambæk, »Forsamlingshuset og dets betydning for foreningerne." I: Hojmark Skytte- og Gymnastikforening 1882-1982 (Ringkøbing 1982), s. 42-50.

K. Larsen, Den tredje bølge - på vej mod en bevaegelseskultur (København 2003).

S. Liedman, I skyggen af fremtiden. Modernitetens idehistorie (København 2000).

H. Lyngsgård, Idrattens rum: nybrud i idrattens arkitektur (København 1990).

V. Møller, »Genius loci - om idrætsrum som hovedsteder.« I: Idratshistorisk Årbog (Odense 1997) s. 125-147.

C. Nielsen, »Øiet aabnes. Legemet udvikles og Hurtigheden skærpes - sportens fremkomst i Århus.« I: Den Jyske Historiker nr. 53. (Århus 1990), s. 65-80.

L. Ottesen \& B. Ibsen, Forsamles og forenes om idrat. (København 2000).

T. Rasmussen, Lederuddannelse og demokrati; en gymnastikhфjskoles historie (Viborg 2001).

K. Susgaard et al., Ølstrup Sogn (Udgivet af Ølstrup Sogneforening 1990).

J.O. Tangen, Making the Space. A Sociological Perspective on Sport and its Facilities. (Upubliceret manuskript 2003).

E. Trangbæk, Mellem leg og disciplin. Gymnastikken i Danmark i 1800-tallet (Viborg 1987).

Y. Tuan, Topophilia. A study of Environmental Perception, Attitudes, and Values. (New York 1974/90). 